\title{
The Application of Music Resources in the Process of Ideological and Political Education under the View of Humanism Education
}

\author{
Meifan Zhu, Wenjing Ai* \\ School of Marxism \\ Wuhan University of Technology \\ Wuhan, P.R.China \\ E-mail:975212912@qq.com; 1043737405@qq.com
}

\begin{abstract}
The ideological and political education work is fundamentally the work of being a man. We must focus on the students, take care of them and serve them. Music resource itself contains the value of moral education, aesthetic education and emotional reinforcement. In order to improve the rigidity and rigidity of ideological and political education, and strengthen its affinity and pertinence, this paper, under the guidance of humanistic education concept, integrates music resources into ideological and political education, so as to make people happy and educate people with music. On this basis, the author puts forward that the principle of practicality, overall planning and pertinence must be adhered to in the process of integration.
\end{abstract}

Keywords-humanism education; ideological and political education; music resources

\section{INTRODUCTION}

General Secretary Xi Jinping emphasized at the National Conference on ideological and political work in Colleges and universities that we should stick to the path of socialist education with Chinese characteristics and cultivate socialist builders and successors who are fully developed by virtue, intelligence and physical culture. In the final analysis, ideological and political education is the work of being a man. We must focus on, care for and serve people. Under such humanistic education ideas, music resources should be integrated into ideological and political education, ways and methods of ideological and political education should be softened, and the aesthetic feeling of ideological and political education should be strengthened, so as to improve the effectiveness of ideological and political education.

\section{The Connotation of The Humanistic View of EDUCATION}

The thought of humanism has gone through the development process from idealism to old materialism and then to dialectical materialism. Among them, Marx's humanism and Rogers' thought are typical. Marx's graduation thesis in 1835, consideration of youth in choosing a career, has elaborated on the issue of life ideal. "But the chief guide which must direct us in the choice of a profession is the welfare of mankind and our own perfection. It should not be thought that these two interests could be in conflict, that one would have to destroy the other"[1]. This is Marx's most exposition of humanism. It can also be said that this is Marx's "original intention" - to liberate, develop and perfect all mankind as the highest goal. He believes that humanism needs to place people in the real social relations, because "the essence of man is no abstract inherent in each single individual. In its reality, it is the ensemble of social relations. "[2] Human beings have subjective initiative, and can consciously and purposefully understand and transform the world. Beauty is an important measure for human beings to transform the subjective and objective world. Human beings should build the world and themselves according to the law of beauty, and ultimately pursue and realize human freedom and liberation. In the late last century, Maslow and Rogers introduced humanism into the field of education, marking the birth of humanism education. Humanism education emphasizes that education should be people-oriented. Educators should not only regard the educated as members of society to carry out basic quality education but also regard the educated as an independent individual to cultivate their abilities in personality, creation and interest. In the process of education, we should guide the educated to accept the content of education actively and freely, and finally achieve the goal of cultivating the all-round development of people.

\section{The VAlue of IDEOlogicAl AND Political EDUCATION OF MUSIC RESOURCES}

In the history of China, there has been a practice of introducing music into ideological and political education. For example, Dong Zhongshu of the Han Dynasty said in the "Countermeasure" that "Benevolence, righteousness, propriety and music are all concrete ways to carry out "Tao". Therefore, after the death of the ancient sage king, his descendants can sit in the world for a long time, and the country has been peaceful for hundreds of years, all of which are the achievements of promoting the education of rites and music. The monarch himself did not make new music, so he chose the music system of the previous monarch that was suitable for the society at that time and used it to further educate the people. Without the actual effect of enlightenment, the music of elegance and praise will not be done. Therefore, the king will not be able to do music until he becomes famous and use music to praise his merits. Music is used to change folk customs and influence 
folk customs; it is easy for music to change folk customs, and it has significant effects on people."[3]

Combine music with politics when answering the emperor's way. For example, the reformers, represented by Kang Youwei and Liang Qichao, put forward music as an emotional and spiritual education to "open people's minds" and "educate new people", and to train "reformers" with bourgeois ideology, new morality, and new spirit.

\section{A. The value of moral education}

The moral education value of music is reflected in its influence on people's growth process. In the process of people's growth and mental structure construction, musical beauty can gradually and firmly form a positive psychological set of love and pursuit of beauty and keen discrimination of beauty and ugliness. With this psychological set and aesthetic value orientation, one can consciously examine one's mind and behavior according to the aesthetic ideal, judge the beauty and ugliness of society and nature, praise all good things, and abhor all ugly phenomena. Through the appreciation of musical beauty, people's strong sense ability and acute and accurate judgment ability of beauty will accumulate in people's psychological structure, forming the psychological set and intuitive ability to treat the object with aesthetic attitude and vision. Under the guidance of the advanced aesthetic ideal, we will shape ourselves by the law of beauty, so that our appearance, behavior, clothing and so on can be united in beauty with our mind, character and emotion. It will also transform the society and the world with advanced aesthetic ideals and rules, so that the social structure, living environment, the relationship between people, the relationship between people and nature can be eased in the aesthetic. In this way, all ugly things, behaviors, ugly customs and habits will be resisted, beautiful things, noble behaviors, noble sentiments, civilized words and deeds, and all innovations beneficial to human society will be respected.[4]

The music itself also embodies the social consciousness of a certain class, era and nation, in which advanced social thoughts, positive outlook on life, progressive political outlook and moral outlook can affect people's consciousness and make their thoughts conform to the trend of historical development. This is another way for music to become good by beauty, that is to say, the good that promotes the correct development of people's thoughts contains the connotation and form of music beauty, which makes people imperceptibly affected in the process of enjoying music beauty.

\section{B. The value of aesthetic education}

Aesthetic education, also known as aesthetic feeling education, is to cultivate people's ability to understand, experience, feel, appreciate and create beauty so that we have the ideal, sentiment, character and accomplishment of beauty.[5] the purpose of aesthetic education is to cultivate one's own life, and its value is to make one's life full of vigor and vitality and freedom. The opinions on strengthening the work of aesthetic education in Colleges and universities in the new era put forward that we should follow the characteristics of aesthetic education, carry forward the spirit of Chinese aesthetic education, and cultivate socialist builders and successors with all-round development of morality, intelligence, body, beauty and labor by means of aesthetic education, beautification and beauty. The opinion points out that school aesthetic education is the work of cultivating the soul, improving students' aesthetic and humanistic quality, and Comprehensively Strengthening and improving aesthetic education is an important task at present and in the future. More and more attention has been paid to aesthetic education.

According to Maslow's demand theory, human needs can be divided into two parts: basic needs and growth needs. There are seven different levels: physiological needs, security needs, belonging and love needs, respect needs, knowledge needs, beauty needs and self-realization needs. From the production of music, it is with the birth and development of human needs, enrichment and improvement, in turn, music also in its own development constantly meet the needs of people's multi-level. Maslow called the short time of self-realization the happiest and happiest time in his life "peak time". Music can constantly make people get a good "peak experience" to sublimate and purify the soul to the most perfect state.[6] The "peak experience" provided by music aesthetics not only meets people's needs for truth, goodness and beauty but also enables people to get the driving force in self-realization. The aesthetic function of music education is to cultivate a scientific aesthetic concept through aesthetic activities, cultivate and exercise the ability to improve the aesthetic ability, that is, the ability to grasp and create freely. It is an important goal of humanism and also the goal of cultivating the free development of human beings to achieve spiritual satisfaction through feeling and experiencing an aesthetic pleasure.

\section{The value of Emotional reinforcement}

The emotional strengthening function of music resources is reflected in the influence of music on people's psychological activities. The influence of music on people starts from psychological activities, which are divided into three parts: informed meaning. The forming process of people's ideology and morality is the dialectical movement and balanced development process of people's internal knowledge, will and action under the influence of certain external environments. Knowledge, that is, ideological and moral knowledge. The influence of music on knowledge is reflected in the overall correspondence of music with the outside world, and the deep expression of the inner world can make people deeply understand the material world of subject and object. For example, from the study of music history, we can get a lot of information related to the era, politics, religion, economy, culture and art. Emotion refers to moral emotion. Music plays an important role in regulating moral emotion. First of all, music can induce people to release positive emotions.[7] Secondly, music can weaken negative emotions and gradually transform them into positive ones. For example, in music therapy, therapists will use music to help patients change their negative emotions. Moreover, music can regulate the intensity, degree and persistence of people's emotional state. The degree to which a person is in a positive and healthy mental state and the unbalanced mental state tends to be balanced. Finally, music can enrich people's emotions and strengthen their ability to bear all kinds of emotions. Xian Dingchang, a high-energy physicist, talked about his feelings for music in the random thoughts of Edinburgh: "it's vast, solemn and strong sound and 
atmosphere resonate with the historical feelings and contemplation of life and death aroused by me in the church tomb so strongly, causing an electric shock in my soul."[8] This kind of music experience fully expresses the influence of music on their sense of beauty and morality. It means that moral will is a psychological process in which people consciously determine their goals and control their actions to overcome difficulties and achieve their goals. In the use of music resources, both music creators and viewers are influenced by music. The process of creators' pursuit of music perfection is the process of continuous strengthening of their spiritual willpower. Not to mention viewers, magnificent style music will always give people courage and strength and enhance people's willpower. For example, few people who listen to Beethoven's symphonies are not excited by his passion, and excellent works always deeply affect people with emotional resonance.

\section{The Principle of The Use of Music ResourCes IN}

\section{THE PROCESS OF IDEOLOGICAL AND POLITICAL EDUCATION}

Music resources play an important role in the process of ideological and political education, but in the process of ideological and political education, the use of music resources still needs to follow the following principles:

\section{A. Principle of practicality}

Our society is in a historical period of comprehensive transformation, and great changes have taken place in various fields such as social economy, politics, ideology and culture. These changes constantly put forward new requirements for people: on the one hand, it requires that every individual should be more active, more reflective and critical, be good at obtaining information, making correct choices and information reorganization, be able to absorb various resources, effectively use and promote self-development, be good at thinking, be good at finding problems and have the ability to solve problems. Such a person is independent, independent, self-control and self-motivated, and has a rich personality. On the other hand, the continuous development of society and the continuous change of culture also gave birth to different kinds and styles of music works. Therefore, it also leads to intermingle of good and bad music resources. Therefore, in the process of ideological and political education, the use of music resources should be carefully considered and carried out flexibly. On the one hand, we can use modern education and teaching methods to highlight the advantages of the integration of ideological and political education and music resources, so that the traditional ideological and political education is more flexible, and we can carry out ideological and political education activities according to local conditions and aptitude. On the other hand, we should strengthen the integration of different types of music and excavate the content of ideological and political education from different types of music. And applied to the ideological and political education process, from the music resources to convey the ideas and emotions to get inspiration. In this way, students not only like this kind of teaching method, but also can have different feelings on the thoughts and emotions contained in music resources, making the use of music resources in ideological and political courses more practical and effective.

\section{B. The principle of coordination}

As the highest level of human spiritual liberation or human spiritual development, "people-oriented" should cover the following three aspects: first, the reasonable settlement of the relationship between human and nature, including the establishment of human subject status and the promotion of scientific spirit. This requires the education of students to treat nature and its relationship with nature scientifically and rationally, and cherish nature and life equally importantly. Second, the relationship between people and society, and the reasonable settlement of the relationship between people, including the principle of reasonable individualism and collectivism. The third is the relationship between people themselves, including the coordinated development of their own material enjoyment and spiritual pursuit. Only when we correctly understand and deal with the relationship between nature, society and humans can we truly understand the connotation of "people-oriented" education philosophy.

First, coordinate the relationship between man and nature. As far as human nature is concerned, ideological and political education should promote human rationality, respect and care for the lover. It is the human reason that makes people choose themselves, create themselves, decide themselves, perfect themselves, develop themselves, and make people understand that they are the creator of their own life and history, the master and God of themselves.[9] man is the product of nature, which is the basis of human survival. Therefore, in the process of ideological and political education, we need to pay attention to people's needs, which is also the starting point of ideological and political education, "everything people strive for is related to their interests", "this kind of education will more emphasize the development of people's potential, especially the potential to become a real person; emphasize understanding oneself and others and get along well with others; It emphasizes meeting the basic needs of human beings and the development towards self-realization. This kind of education will help "people to become the best people as they can."[10] In the process of ideological and political education, we must pay attention to the needs of the "real people" who are the objects of education. Only by solving the needs and paying attention to their natural nature, can we better achieve the goal of education.

Second, coordinate the relationship between people and society. That is to create a good ideological and political education environment. The essence of the human is in its sociality. The biggest environment of human life is society. Humanism attaches great importance to the overall development of human beings. ideological and political education should cultivate "complete human beings". With the change of social life, people's experiences and needs are constantly changing. The goal of education is no longer to impart knowledge and improve intelligence, but to cultivate good emotions and values of individuals. However, in the traditional ideological and political education, we pay attention to the evaluation, supervision and restriction of students' values, norms, conduct and sentiment, and do not pay enough attention and concern to students' growth space and inner pressure. Therefore, in the process of ideological and political education, music resources are used to add aesthetic feeling to the original dull and oppressive ideological and political education. By 
creating an environment of emotional interaction and exchange between the subject and object of education, the educated can integrate into the environment harmoniously and achieve the effect of emotional fluency.

\section{The principle of targeting}

First, the target of education. The object of ideological and political education refers to an extremely complex aggregation that can be divided into different types and levels. Different types and levels of educational objects have different characteristics, which need to be analyzed. The object of ideological and political education is not an abstract person, but a real person. Because of different growth environments, life experience, knowledge background, social identity and other differences, people, in reality, will show different social attributes and practice, spatial attributes, different ideological characteristics, and obvious levels.[11] When using music resources, ideological and political educators need to select different types and characteristics of music according to the different objects of ideological and political education, so as to achieve the fitness of ideological and political education content and objects, and thus strengthen the effectiveness of ideological and political education. The object of ideological and political education has the characteristics of subjectivity, which requires that we should not only regard education as a kind of "container" to be filled but also as an object to be "instilled". Instead, we should regard the object of ideological and political education as a real person, people-oriented, concerned about the inner spiritual needs of the object of education, and guide and stimulate the subject initiative of the object of education. So that the education objects can participate in the ideological and political education activities more actively and rationally, and achieve the goal of ideological and political education in the interaction with the conscience of educators.

Second, the pertinence of education content. The pertinence of educational content means that the ideological and political educators should select music resources pertinently in the process of ideological and political education. First of all, when using music resources, we should pay attention to whether the selected resources are consistent with the educational objectives of ideological and political education, which should not be far-fetched. When we hear music, the educational objects should naturally be able to contact the teaching content, so as to achieve the set educational objectives. Secondly, the music resources selected by ideological and political educators are targeted in improving students' abilities. In short, it means that after listening to the songs and learning the knowledge, the education object will be able to guide his behavior with the thought he has learned. Of course, this behavior must be positive and healthy. Finally, the music resources selected by ideological and political educators should be targeted in terms of emotional attitude and values. The essence of ideological and political education is to carry out moral education, help them form correct three views and cultivate noble moral quality. With the continuous influx of the trend of the times, every corner of the society is full of pop music. ideological and political educators can't exclude pop music, ideological and political classroom can't exclude pop music, as long as it can help to achieve the teaching goals.
Third, the pertinence of the education process. The process of ideological and political education is to solve the contradiction between the ideological and moral requirements of a certain society and the ideological and moral requirements of the educatee in the century and the ideological and moral level of the educatee in the century, so as to promote the moral development of the ideological and political object to the direction of social requirements, so as to promote the overall development of the educatee.[12] In the process of ideological and political education, the use of music resources by ideological and political educators must have clear planning and distinct correctness. ideological and political education should promote the prosperity and progress of society and the all-round development of people. Its value content system must be composed of parts that are conducive to social development and personal happiness. This requires that the selected music resources must have planned and purposeful educational activities carried out consciously according to certain social requirements and the needs of the spiritual world development of the educated.

\section{CONCLUSION}

With the continuous development of society, the requirements for personnel training are also constantly improving. The main social contradictions are transformed into the relationship between the people's growing needs for a better life and unbalanced and inadequate development.[13] This means that people's demand for beauty will be higher and higher. The integration of ideological and political education and aesthetic education is also imminent. Making full and reasonable use of music resources in the process of ideological and political education is an important way for the development of ideological and political education.

\section{ACKNOWLEDGMENT}

This paper is supported by the Ministry of Education 2016 Chinese Excellent Cultural and Art Inheritance Project (444-11075)

\section{REFERENCES}

[1] Selected Works of Marx and Engels, Vol. 1, Beijing: People's Publishing House, 1995, pp. 414. (In Chinese)

[2] Selected Works of Marx and Engels, Vol. 1, Beijing: People's Publishing House, 1995, p. 18. (In Chinese)

[3] Han Shu [M]. Zhonghua Book Company, (Han) class solid writing, 2005. (In Chinese)

[4] Chen Jian. On the Concept of "Positive Music" in Chinese Modern Music Education Thoughts[J]. Dongyue Theory, 2018, 39(09): 59-65. (In Chinese)

[5] Zhang Zhengjiang, Research on the Development of Aesthetic Education in New China [M], Beijing: People's Publishing House, 2014. (In Chinese)

[6] Luo Xiaoping, Huang Hong. Music Psychology (Second Edition) [M]. Shanghai: Shanghai Conservatory of Music Press, 2008. (In Chinese)

[7] Zeng Yujin. Musical Sociology [M]. Shanghai: Shanghai Conservatory of Music Press, 2004. (In Chinese)

[8] Luo Xiaoping, Huang Hong. Music Psychology (Second Edition) [M]. Shanghai: Shanghai Conservatory of Music Press, 2008. (In Chinese)

[9] Theory Department of the Central Propaganda Department. Theoretical hotspots 18 questions [M]. Beijing: Learning Press, 2004. (In Chinese) 
[12] Chen Wanbai, Zhang Yaocan. Principles of ideological and Political Education (Third Edition) [M]. Beijing: Higher Education Press, 2015. (In Chinese)

Chen Hongwen, Trans. Shanghai: Shanghai Translation Publishing House, 1987. (In Chinese)

[11] Chen Wanbai, Zhang Yaocan. Principles of ideological and Political Education (Third Edition) [M]. Beijing: Higher Education Press, 2015. (In Chinese)

[13] Xi Jinping. Decisive victory to build a well-off society in an all-round way to win a great victory in socialism with Chinese characteristics in the new era - Report at the 19th National Congress of the Communist Party of China [N]. People's Daily, 2017-10-28.(In Chinese) 